\title{
Effects of controllable and uncontrollable parameters on diamond wire cutting performance using statistical analysis: a case study
}

Rudarsko-geološko-naftni zbornik

(The Mining-Geology-Petroleum Engineering Bulletin) UDC: 622.2

DOI: $10.17794 / \operatorname{rgn} .2021 .4 \cdot 3$

Original scientific paper

\author{
Arezou Rasti'; Hamid Ranjkesh Adarmanabadi'; Mohammad Reza Sahlabadi \\ ${ }^{1}$ Department of Mineral Engineering, New Mexico Institute of Mining and Technology, Socorro, NM, United States \\ ${ }^{2}$ Department of Technical and Engineering, Islamic Azad University Science and Research Branch, Tehran, Iran
}

\begin{abstract}
Nowadays, most mining and quarrying industries utilize a diamond wire saw machine for bench cutting operations. This method uses a metal wire or cable assembled by diamond beads to cut the hard stone into large blocks. Many parameters classified into controllable and uncontrollable parameters affect the performance of the diamond wire saw cutting method. The uncontrollable parameters are related to rock engineering properties, and controllable parameters are related to operational aspects and machine performance. The diamond wire sawing process's production rate is one of the most critical parameters influencing the design optimization and quarrying cost estimation. The cutting rate and wear rate of diamond beads are the most important factors to evaluate quarries' production performance. This study aims to determine the effects of different controllable and uncontrollable parameters on different quarries' production rates. Rock engineering properties like strength, hardness, and abrasivity, and operational aspects, such as cutting angle and drive wheel diameters, are considered as the main factors affecting the production performance of the diamond wire saw method. To discover the influence of these parameters, a detailed investigation in ten quarry operations was carried out. The relation between cutting rate and diamond bead wear with different parameters is estimated. It was observed that different controllable and uncontrollable parameters could increase or decrease the cutting rate and diamond bead wearing. Furthermore, using simple and multiple regression analysis, performance prediction of the cutting rate and wearing of diamond beads was developed, and the best equations were proposed.
\end{abstract}

\section{Keywords:}

diamond wire cutting method; cutting rate; wear rate; regression analysis; controllable and uncontrollable parameters

\section{Introduction}

One of the extensive purposes of dimension stone quarrying is producing rock blocks in different sizes and geometry at the optimum cost. Different methods have been used for quarrying, but recently, the diamond wire saw cutting method has been widely used to extract stones from their natural bed (Mikaeil et al., 2018). It is necessary to perform geological and engineering geological studies before the production process. Applying an appropriate production pattern according to the geological studies will reduce the production losses. (M. Ozcelik and Leventeli, 2019). Due to increased interest in the dimension stone industry and using the wire saw cutting method for operation, this method's productivity plays a crucial role in mining cost. Different parameters affect the productivity and efficiency of the diamond wire saw cutting method in quarrying.

Various parameters affecting the cutting process are classified as stone characteristics, cutting characteristics,

Corresponding author: Hamid Ranjkesh Adarmanabadi

Hamid.ranjkesh@student.nmt.edu and management characteristics (Mikaeil et al., 2011). Some studies investigated the effects of a stone's geomechanical parameters on the cutting rate (Mikaeil et al., 2021; Fener et al., 2007). The effects of rock properties and operation properties on the penetration rate of different rocks were evaluated by (Yassien et al., 2020). The results indicated that rock properties including compressive strength (CS), tensile strength (TS), and density have a significant effect on the penetration rate. A good relationship between the rock brittleness index and the production rate of ornamental stone for different rock types was observed. The production rate decreased with an increase in the brittleness index (Mikaeil et al., 2013). The effects of rock anisotropy and cutting angle on the efficiency of diamond wire cutting machines were investigated. The results showed that the diamond wire cutting productivity is sensitive to rock anisotropy and the cutting angle, and as the cutting angle increases, the cutting ratio decrease (Ozcelik and Yilmazkaya, 2011). Additionally, the relation between cutting ratio and rock hardness, porosity, and density were reviewed. It was concluded that the production rate increases by increasing the rock porosity and decreasing the rock density and 
indentation hardness index (Kahraman and Gunaydin, 2008). The effects of uniaxial compression strength, quartz content, and elasticity modulus on the production rate of diamond wire saw on different carbonate rocks were surveyed. It was remarked that the production rate increases with a decrease in uniaxial strength, quartz content, and elasticity modulus (Sadegheslam et al., 2013). Generally, rock sawability depends on a wide range of mineralogical and strength properties of the rock. Rajpurohit et al. (2020) performed a study to investigate the effects of different rock properties on the sawability of a diamond wire saw. A linear correlation between the cutting rate and rock properties, such as strength, p-wave velocity, brittleness, and abrasivity was observed. The results indicate that the rock cutting rate using a diamond wire saw is more influenced by rock tensile strength, abrasivity, and brittleness. The effects of different rock characteristics on carbonate rock's specific energy showed that rock strength, hardness, and porosity have the highest effect on specific energy compared with other parameters (Sengun and Altindag, 2013; Hosseini et al., 2019). The effects of physical and mechanical properties of rock and operating parameters, including density, abrasivity, wave velocity, and amperage on the specific energy of diamond wire, were investigated by Khoshouei et al. (2020). The results indicated that all parameters have a significant effect on the wire diamond specific energy consumption, and by knowing the rock properties, the specific energy can be predicted with an accuracy of more than $85 \%$. The textural properties of rock, including grain size, shape and orientation, and proportion of grains, significantly affect the cutting performance. There is a strong relationship between the cutting ratio and area of grain, texture coefficient, and diameter equivalent. As these parameters increase, the cutting rate decreases (Ghaysari et al., 2012).

On the other hand, the operating parameters and cutting characteristics have a notable effect on the diamond wire cutting method's productivity. It was observed that by reducing the diamond particle size while they have the same hardness in segment structure, the fragment capacity would be decreased, and energy consumption would increase (Luo and Liao, 1995). The wear rate of beads is a critical factor due to its effect on productivity and operating cost. The effects of cutting mode on the wear and specific energy consumption were evaluated by applying different cutting modes on some granites. The specific wear rate and specific energy consumption results demonstrated that the up-cutting mode is more efficient than the down-cutting mode (Buyuksagis, 2007). The investigation was performed to evaluate the performance of chain saw machines by improving a certain tool lacing. By modifying the position of tools, the cutting rate increased, and the wear rate was reduced (Hekimoglu, 2014). The efficiency and number of diamond beads in a unit length of diamond wire have a significant impact on the cutting efficiency. It was observed that the efficiency of diamond beads is higher at the middle third of their lifetime, and there is an optimum mode for the number of beads. First, with an increase in bead number to reach the optimum mode, the cutting rate increases, and after the optimum mode, the increase in bead number, causes a decrease in the cutting rate (Bagherpour et al., 2014). Additionally, it was concluded that the sawed area increased with a decrease in the diameter and number of diamond beads (Careddu et al., 2019). Different diamond wire machines with a variety of power were utilized for the cutting process. The power of motors was different, and by increasing the power, the wire velocity increased. With an increase in the wire velocity, the wire saw's productivity rose; however, the wear rate also increased (Hawkins et al., 1990). One of the most important factors in the wire diamond cutting process is the wear rate of diamond beads. The effects of rock characterization and operating parameters on the wear rate of diamond beads were investigated (Najmedin Almasi et al., 2017). It was observed that rock properties affect the wear rate significantly, and production rate influences the lifetime of the diamond beads.

Numerous parameters affect the efficiency of the wire saw cutting method in quarries. All parameters are divided into two main groups: controllable and uncontrollable factors. The uncontrollable parameters are always constant, such as rock texture and engineering properties. The controllable parameters vary based on various cutting methods and different types of rocks. The controllable parameters include the machine's power, wire velocity, and number and type of beads. This research aims to evaluate the effects of controllable and uncontrollable parameters on the efficiency of cutting productivity in different quarries. For this purpose, simple and multiple regression analysis is applied to determine the best model. Furthermore, the efficiency of this method is evaluated at different wear rates of diamond wire beads.

\section{Diamond wire saw operation}

Using a diamond wire saw machine to produce good quality rocks in quarries is the most common method in most countries. This method has been developed multiple times to improve its performance. Figure 1 illustrates the diamond wire and its different parts. The wire cutting is composed of a stainless steel cable and some diamond beads, steel springs, crimps, and steel coupling mounted on the steel cable (Özçelik et al., 2002). The diamond wire can be assembled differently based on the mechanical properties of cutting wire segments and rock type. The diamond beads which provide the actual cutting action are simple cylindrical rings bonded with abrasive materials by sintering or electroplating techniques (Almasi et al., 2015).

Some vertical and horizontal holes with an intersection of a 90-degree angle are drilled through the block using the wire cutting method. This method's principle 


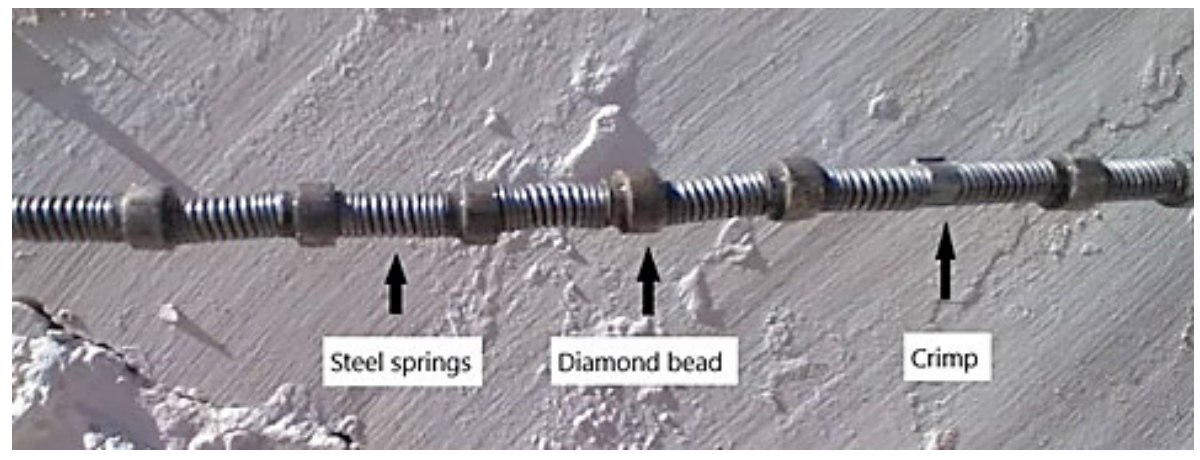

Figure 1: Diamond wire

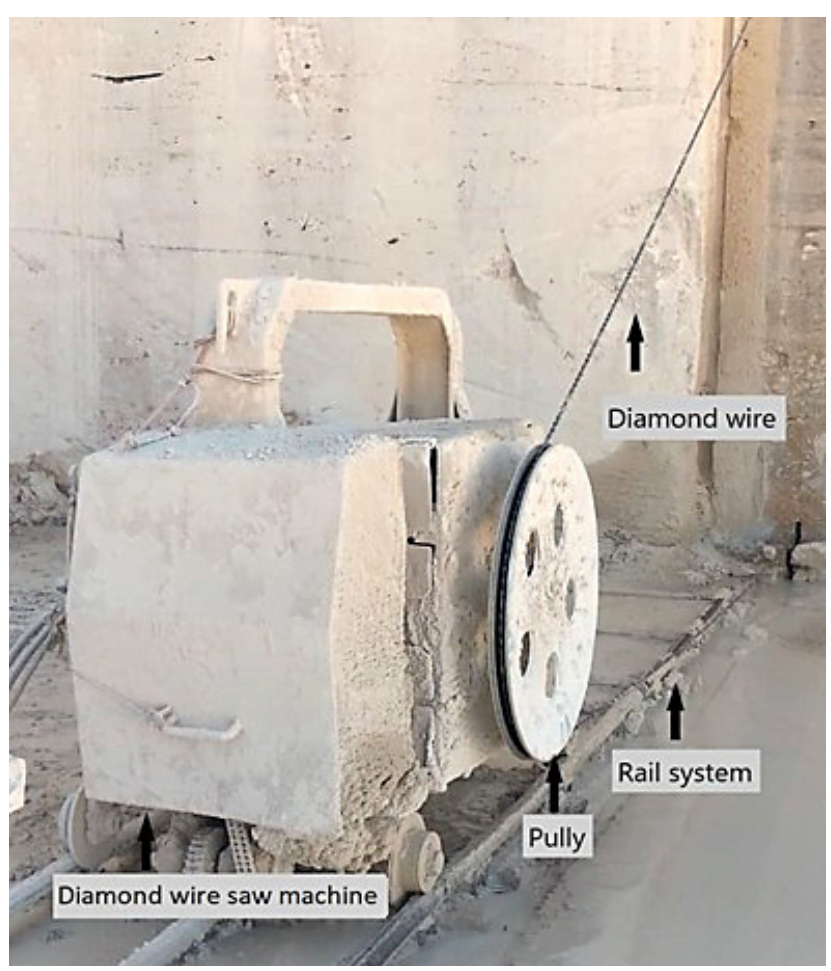

Figure 2: Diamond wire saw machine used for a vertical cut

is to abrase the rock, which occurs with the movement of diamond beads over the rock (Bilim \& Karakaya, 2021). For this reason, the diamond wire is passed through the holes that are perpendicular to each other and mounted around the pulley of the wire cutting machine. The two ends are clamped together to form a continuous loop. The pulley can be set at any angle based on the cutting direction, and by the pulley movement, the diamond wire rotates through the block. The cutting process's required force is obtained by the backward movement of the diamond wire machine on the rail. When the machine reaches the rail's end, the diamond wire's length is decreased, and the machine returns to its starting point to continue the cutting process, and this loop is repeated to finish the cutting. Figure 2 presents the diamond wire machine and diamond wire located through the block for the cutting process. It was observed that the maximum force applied during the cutting process oc- curs when the diamond bead is about to leave the cutting surface. During the cutting process, water is supplied with the wire's spin direction as a coolant and removes the waste particles through the cutting direction. Various types of diamond wire are used in a dry conditions and do not need a coolant during the cutting process (Almasi et al., 2015; Bilim and Karakaya, 2021).

\section{Materials and method}

To evaluate the diamond wire cutting performance on different carbonate rocks, ten different quarries located in the Isfahan Province were selected. The diamond wire saw was used in all the quarries to cut the primary block with a typical dimension of $9 \mathrm{~m}^{*} 9 \mathrm{~m} * 8 \mathrm{~m}$. The wire saw machines used for cutting were similar with the same speeds and power based on their features. The features of diamond wire saw machines used in the studies are presented in the Table 1. The diamond wire performance based on the various controllable and uncontrollable parameters was measured. In this study, the rock geomechanical properties, such as strength, hardness, and abrasiveness are considered uncontrollable parameters. For this reason, the uniaxial compression strength was selected as the strength properties (Ranjkesh Adarmanabadi et al., 2021). Schmidt hammer value and Los Angeles abrasion were measured as the hardness and abrasion parameters, respectively. The machines' power and speed, cutting angle, and wheel drive diameter are considered controllable parameters.

The cutting rate was measured as the area cut by diamond wire per unit time during the actual rock cutting. Equation 1 was used to measure the cutting rate at different quarries.

$$
C R=\frac{A}{t}
$$

Where:

$\mathrm{CR}$ - cutting rate $\left(\mathrm{m}^{2} / \mathrm{h}\right)$,

A - area of cutting surface $\left(\mathrm{m}^{2}\right)$,

$\mathrm{t}$ - cutting time (h).

In ten quarries, the cutting rate for different surface cutting was measured, and an average was calculated for 
the cutting rate. The cutting rate was measured at a different angle of 0,30 , and 90 degrees using a diamond wire saw machine. To evaluate the effects of different parameters on the wear rate of diamond beads, the diamond beads' wear rate was measured after several surface cuttings using the Equation 2. The wear rate of a bead is a tool to measure the consumption in the cutting method.

$$
W R=\frac{d-d_{0}}{A}
$$

Where:

WR - wear rate $\left(\mu \mathrm{m} / \mathrm{m}^{2}\right)$,

d - diameter of bead before using $(\mu \mathrm{m})$,

$\mathrm{d}_{0}$ - diameter of bead after cutting $(\mu \mathrm{m})$,

A - area of cutting surface $\left(\mathrm{m}^{2}\right)$.

A digital micrometer was used to measure the diameter of the beads. The average diameter of a bead before cutting the surface was $11.5 \mathrm{~mm}$, and after cutting, when the beads were worn out, their diameters were measured as the final measurement. To measure the wear rate of the beads, one-quarter of the wire length beads were separated from the wire after cutting. The diameter of the worn beads was measured from different sides of the beads, and an average was calculated.

To determine the rock properties, rock samples were collected from the investigated quarries. The collected rock samples in the mines were big enough to prepare

Table 1:: Specification of diamond wire cutting machine

\begin{tabular}{|l|l|}
\hline Description & Values of machine \\
\hline Main motor power $(\mathrm{KW})$ & $50 \mathrm{~kW}$ \\
\hline DC motor for wire tensioning $(\mathrm{kW})$ & $0.75 \mathrm{~kW}$ \\
\hline Rotator diameter $(\mathrm{cm})$ & $70-90 \mathrm{~mm}$ \\
\hline Linear speed $(\mathrm{m} / \mathrm{s})$ & $28-30 \mathrm{~m} / \mathrm{s}$ \\
\hline Length of wire $(\mathrm{m})$ & $50 \mathrm{~m}$ \\
\hline Beads per meter & $31-34$ \\
\hline Diameter of fresh bead $(\mathrm{mm})$ & 11.5 \\
\hline Bead type & Sintered \\
\hline
\end{tabular}

specimens in an appropriate size for different tests. The specimens were prepared in the lab using the coring and cutting equipment. A series of laboratory tests were conducted to estimate the different rock sample properties, including specific gravity according to (ASTM D647315), uniaxial compression strength according to (ASTM C170), Schmidt hammer according to (ASTM D587314), and Los Angeles abrasion according to (ASTM C131).

The effects of different controllable and uncontrollable parameters on cutting rate and wear rate of beads were evaluated. Simple and multiple regression analyses were performed to find the best model to predict the cutting rate and wear rate based on the rock properties and production aspects.

\section{Results and Discussion}

The physio-mechanical properties of rock samples obtained in the laboratory are summarized in Table 2.

It can be seen from the laboratory results that the specific gravity, uniaxial compression strength, and Schmidt hammer follow the same pattern. The data are collected for different cutting angles of 0,30 , and 90 degrees to evaluate the effects of the angle on the cutting rate. The wear rate of beads is measured after cutting a specific surface area at different angles. The measured cutting rate and wear rate for different quarries are summarized in the Table 3.

\subsection{Effects of uncontrollable parameters on the cutting rate}

One of the most important parameters of rock is rock strength. A quarry is classified into three geologies: soft, medium, and hard rock materials (Bilodeau et al., 2008). The uniaxial compression strength of rock is mostly used to describe rock's strength properties, which is also an important factor in many rock mass classifications. Many parameters of rock including the porosity, specific gravity, weathering, discontinuity network, and constitutive minerals have an effect on the rock strength. There-

Table 2: Geotechnical properties of rocks in different quarries

\begin{tabular}{|l|l|l|l|l|l|l|}
\hline Sample number & Rock type & Color & Gs & UCS (MPa) & B (SH) & LA (\%) \\
\hline Q1 & Limestone & White & 2.7 & 95.5 & 57.8 & 28.4 \\
\hline Q2 & Limestone & White & 2.65 & 90.3 & 56.3 & 31.6 \\
\hline Q3 & Limestone & Orange & 2.73 & 97.5 & 58.6 & 29.7 \\
\hline Q4 & Limestone & Gray & 2.62 & 81.7 & 53.3 & 33.5 \\
\hline Q5 & Marble & Gray & 2.63 & 77.6 & 52.6 & 42.7 \\
\hline Q6 & Travertine & Brown & 2.48 & 58.7 & 52 & 45.7 \\
\hline Q8 & Travertine & Light brown & 2.52 & 70.2 & 51.8 & 38.6 \\
\hline Q9 & Travertine & Cream & 2.57 & 65 & 50.6 & 43.2 \\
\hline Q10 & Travertine & White & 2.5 & 60.5 & 49.4 & 39.8 \\
\hline
\end{tabular}


Table 3: Results of diamond wire cutting operation in different angles

\begin{tabular}{|c|c|c|c|c|c|c|c|c|c|c|c|c|}
\hline \multirow[b]{2}{*}{ Quarry } & \multicolumn{4}{|c|}{ Cutting Angle: $0^{\circ}$} & \multicolumn{4}{|c|}{ Cutting Angle: $\mathbf{3 0}^{\circ}$} & \multicolumn{4}{|c|}{ Cutting Angle: $\mathbf{9 0}^{\circ}$} \\
\hline & $\begin{array}{l}\text { Cutting } \\
\text { area }\left(\mathbf{m}^{2}\right)\end{array}$ & hour & \begin{tabular}{|l|} 
CR \\
$\left(\mathrm{m}^{2} / \mathrm{h}\right)$
\end{tabular} & \begin{tabular}{|l|}
$\mathbf{W R}$ \\
$\left(\mu \mathrm{m} / \mathbf{m}^{2}\right)$
\end{tabular} & $\begin{array}{l}\text { Cutting } \\
\text { area }\left(\mathbf{m}^{2}\right)\end{array}$ & hour & \begin{tabular}{|l|} 
CR \\
$\left(\mathbf{m}^{2} / \mathbf{h}\right)$
\end{tabular} & \begin{tabular}{|l|}
$\mathbf{W R}$ \\
$\left(\mu \mathrm{m} / \mathrm{m}^{2}\right)$
\end{tabular} & $\begin{array}{l}\text { Cutting } \\
\text { area }\left(\mathbf{m}^{2}\right)\end{array}$ & hour & \begin{tabular}{|l|} 
CR \\
$\left(\mathrm{m}^{2} / \mathbf{h}\right)$
\end{tabular} & $\begin{array}{l}\text { WR } \\
\left(\mu \mathrm{m} / \mathrm{m}^{2}\right)\end{array}$ \\
\hline Q1 & 231.76 & 42.45 & 5.46 & 2.96 & 98.76 & 20.07 & 4.92 & 3.07 & 122.34 & 28.92 & 4.23 & 3.76 \\
\hline Q2 & 197.67 & 36.07 & 5.84 & 2.72 & 112.34 & 21.69 & 5.18 & 3.01 & 138.45 & 33.93 & 4.08 & 3.19 \\
\hline Q3 & 215,8 & 42.15 & 5.12 & 2.98 & 123.65 & 27.9 & 4.43 & 3.1 & 110.2 & 28.47 & 3.87 & 3.33 \\
\hline Q4 & 200.65 & 29 & 6.92 & 2.15 & 78.56 & 13.01 & 6.04 & 2.55 & 95.46 & 16.63 & 5.74 & 2.69 \\
\hline Q5 & 278.96 & 43.12 & 6.47 & 2.59 & 102.3 & 17.52 & 5.84 & 3.02 & 210.45 & 40.24 & 5.23 & 3.22 \\
\hline Q6 & 185.67 & 18.95 & 9.8 & 1.52 & 165.34 & 17.5 & 9.45 & 1.6 & 134.78 & 17.83 & 7.56 & 1.94 \\
\hline Q7 & 256.78 & 34.1 & 7.53 & 2.83 & 63.78 & 8.97 & 7.11 & 2.96 & 100.65 & 15.95 & 6.31 & 3.2 \\
\hline Q8 & 154.65 & 18.28 & 8.46 & 1.98 & 132.41 & 16.55 & 8 & 2.21 & 165.9 & 27.11 & 6.12 & 2.38 \\
\hline Q9 & 135.42 & 16.12 & 8.4 & 1.86 & 155.67 & 19.34 & 8.05 & 2.05 & 88.97 & 13.04 & 6.82 & 2.34 \\
\hline Q10 & 206.3 & 26.62 & 7.75 & 2.35 & 86.73 & 12 & 7.23 & 2.62 & 124.67 & 19.15 & 6.51 & 2.9 \\
\hline
\end{tabular}

fore, the uniaxial compression strength can represent many engineering and textural properties of rock. To measure the rock's uniaxial compression strength, the length to diameter ratio of the specimen used was $2.5: 1$, and a testing machine with a capacity of $5000 \mathrm{kN}$ was used to perform the test. The cutting rate of different quarries at different angles versus the uniaxial compression strength of rocks are plotted in Figure 3. The results indicate that the cutting rate decreases with an increase in the rock strength. A simple regression analysis was performed, and Equation 3 through Equation 5 are the proposed equations with the highest coefficient of correlation for the relation between the rock strength and cutting rate at different cutting angles:

$$
\begin{gathered}
C R=700 \times U C S^{-1.1}, R^{2}=0.94, \mathrm{CA}=0^{\circ} \\
C R=1438 \times U C S^{-1.25}, R^{2}=0.95, \mathrm{CA}=30^{\circ} \\
C R=877.5 \times U C S^{-1.2}, R^{2}=0.91, \mathrm{CA}=90^{\circ}
\end{gathered}
$$

To measure the resistance and elastic properties of the rock minerals, a Schmidt hammer test was conducted. The samples were prepared with an approximate dimension of $20 * 20 * 15 \mathrm{~cm}$, and an N-type hammer with an impact energy of $2.215 \mathrm{Nm}$ was used to perform the tests. The hammer hit the rock surface vertically downward, and the test equipment measured its rebound. The rock surface and hammer's angle affect the rebound results, and the test should be done at a right angle to a flat and smooth surface (Brown, 1981). Figure 4 presents the relation between the rock hardness (B) and cutting rate with a different cutting angle. It can be seen that the production rate increases with a decrease in the Schmidt hammer value. There is a power relation between the cutting rate and rock hardness with a good coefficient of correlation (Equation 6 through Equation 8).

$$
\begin{gathered}
C R=1 E+06 \times B^{-3}, R^{2}=0.76, \mathrm{CA}=0^{\circ} \\
C R=1 E+07 \times B^{-3.6}, R^{2}=0.75, \mathrm{CA}=30^{\circ} \\
C R=7 E+06 \times B^{-3.5}, R^{2}=0.82, \mathrm{CA}=90^{\circ}
\end{gathered}
$$

To evaluate the toughness and abrasion characteristics of rock samples, the Los Angeles abrasion test was performed according to the ASTM C131. Abrasion is the measured degradation of a rock surface by friction between the rock particles and steel spheres during their movement in a rotating drum. Rock hardness, concentration, velocity, and mass of the moving particles significantly affect the intensity of abrasion. The test specimens were oven-dried for 24 hours. Approximately $5000 \mathrm{~g}$ of specimen was cooled at room temperature and placed in the drum for rotation with six steel spheres. After the experiment, the amount of materials passed the standard sieve number 12 per the original weight as a percentage recorded for rock abrasion. The relation between rock sample abrasion and cutting rate is presented in the Figure 5. There is a correlation between cutting rate and Los Angeles abrasion. The relation follows a power function with a good coefficient of correlation, and with an increase in the Los Angeles abrasion, the cutting rate increases (Equation 9 through Equation 11).

$$
\begin{gathered}
C R=0.207 \times L A^{0.99}, R^{2}=0.63, \mathrm{CA}=0^{\circ} \\
C R=0.106 \times L A^{1.1}, R^{2}=0.65, \mathrm{CA}=30^{\circ} \\
C R=0.147 \times L A^{1.02}, R^{2}=0.65, \mathrm{CA}=90^{\circ}
\end{gathered}
$$

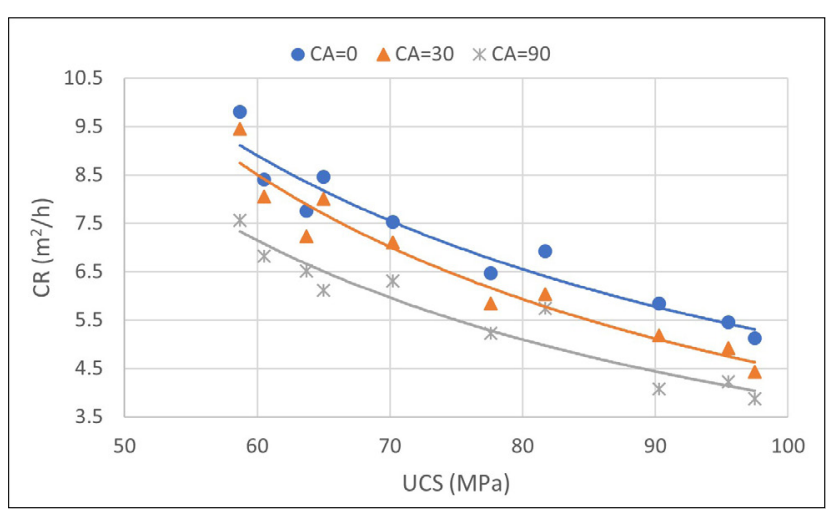

Figure 3: Cutting rate versus UCS 


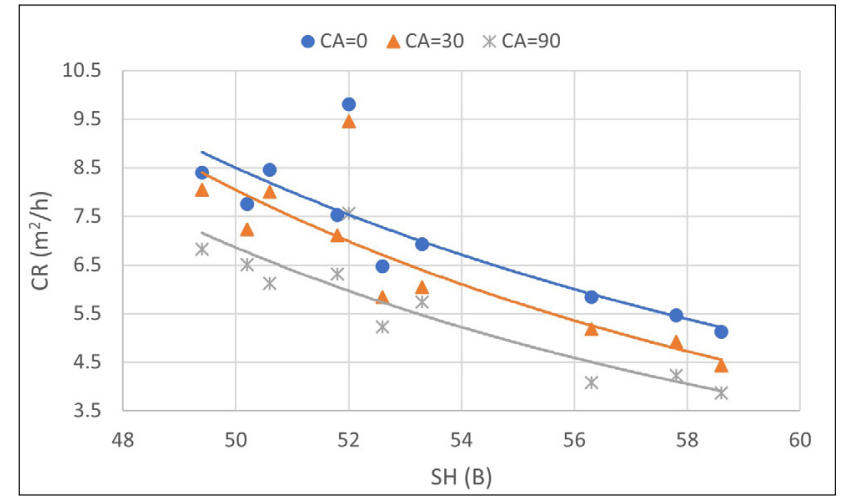

Figure 4: Cutting rate versus Rock hardness (B)

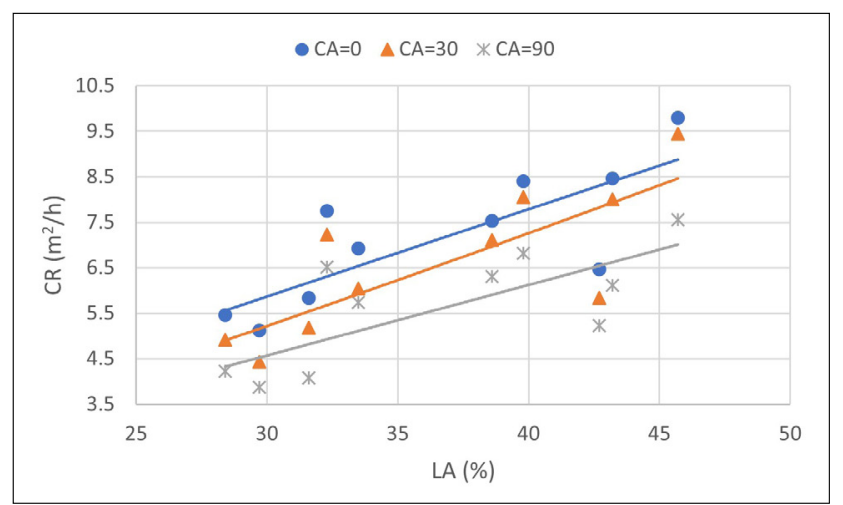

Figure 5: Cutting rate versus Los Angeles abrasion

\subsection{Effects of controllable parameters on production rate}

One of the most significant factors affecting the diamond wire cutting method's productivity is the cutting angle. A quarry cutting angle can be changed from 0 to 90 degrees for cutting a block in different directions. For the most part in the quarries, the cutting angle for cutting a block wall is set as 0 degrees. However, based on the discontinuities network and direction, it can be changed to a maximum of 45 degrees. Cutting with a 90 degree angle is mostly for cutting a block floor. For cutting a block with an angle of 0 degrees, the pulley is set parallel to the diamond wire saw machines on the left or right side. By increasing the cutting angle, the pulley will move to set as the intended angle, and at the maximum, it can reach the 90 degree angle in which the pulley will be set at the machine's bottom. The pressure on the machine during the cutting of the block's floor will increase, and as a result, the diamond wire will piece apart. Therefore, in quarries for cutting with a 90 degree angle, the operators reduce the machines' rotation speed, and the cutting speed will decrease. The cutting angle for the quarries used in this study was 0,30 , and 90 degrees, and all data was collected for these angles. To measure the cutting rate for 90 degrees, a reduction in the cutting speed was considered. The relation between the cutting angle and cutting rate at different quarries is presented in
Figure 6. The graphs illustrate the cutting rate increase with a decrease in the cutting angle, and the cutting angle of 0 has the highest productivity. The maximum reduction due to an increase in the cutting angle is recorded at about 30 percent for a cutting angle of 90 degrees. A simple power function with a good coefficient of determination for the relation between the cutting rate and cutting angle is proposed (Equation 12).

$$
C R=5.95 \times C A^{-0.02}, R^{2}=0.82
$$

Where CA is the cutting angle, and the constant value is changing based on the rock engineering properties.

In the diamond wire cutting method, the diamond wire mounts around the drive wheel of the diamond wire cutting machine, and the wire rotates through the block by the movement of the drive wheel. In this process, the drive wheel or pulley plays a crucial role. The drive wheels are made in different diameters, and the diameter of the pulley can be changed from 60 to $90 \mathrm{~cm}$. By increasing the pulley diameter, the diamond wire speed will increase. During this investigation, some quarries performed the cutting process with a different drive wheel, and the necessary data were collected to determine the effects of pulley diameters on the cutting productivity. The data are collected in four quarries for different pulley diameters of 70,80 , and $90 \mathrm{~cm}$. The relation between the drive wheel's diameter and the cutting rate is presented in Figure 7. The results indicate that an increase in the diameter of the drive wheel also increases the cutting rate.

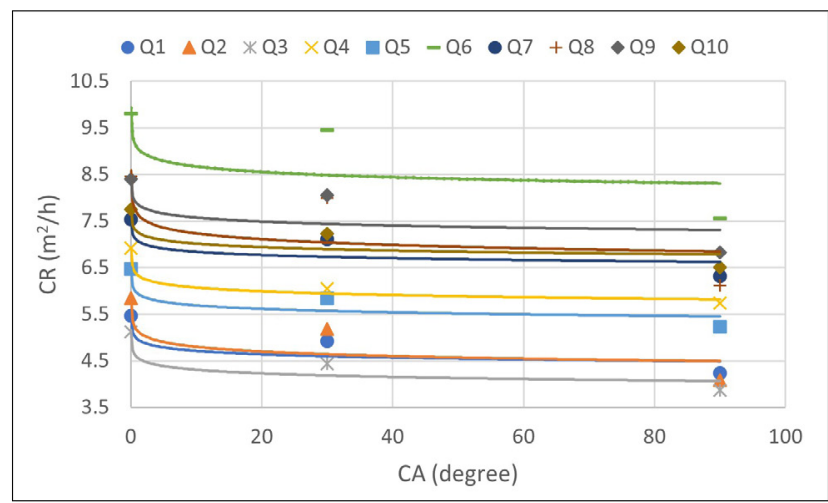

Figure 6: Cutting rate versus different cutting angle

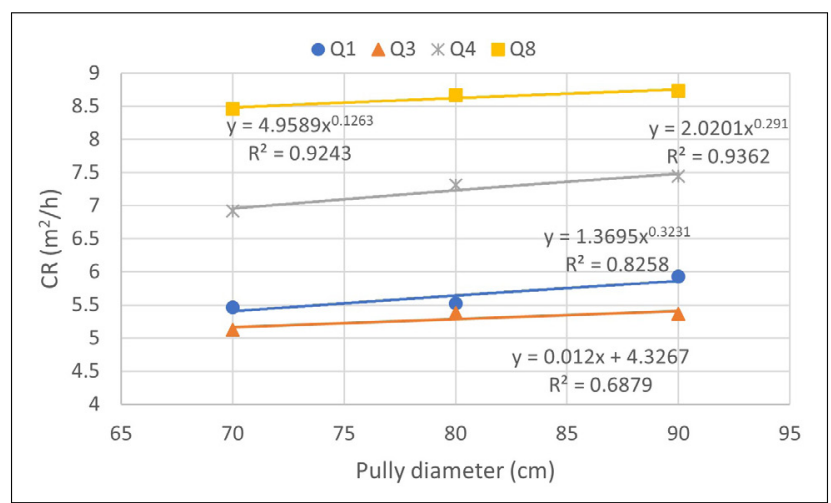

Figure 7: Cutting rate versus wheel drive diameter 


\subsection{Wear rate}

One of the most critical factors affecting the economics of diamond wire cutting is the wear on diamond beads. By reducing the wear of diamond beads, the cost of the diamond wire cutting method will decrease. Many parameters can affect the wear of diamond beads, especially the rock's engineering and textural properties. The relationships between the diamond bead's wear rate in the diamond wire cutting method and textural, mineralogical, and engineering properties of rock were investigated and analyzed by researchers (Bortolussi et al., 1990; Ranjkesh Adarmanabadi et al., 2021). Several beads were separated from the wire after a particular amount of cutting to measure the diamond beads' wear rate. A digital micrometer was used to measure the diameter of the used diamond beads, and an average value was considered for measuring the wear rate. A relation between the cutting rate and some rock's physicomechanical properties with the wear rate of diamond beads are plotted in the Figure 8, Figure 9, Figure 10, Figure 11, and Figure 12. It can be seen that the wear rate increases by increasing the UCS, Schmitt hammer and cutting angle and decreases by increasing the Los Angeles abrasion and cutting rate.

The coefficient of determination for the relationship between cutting rate and wear rate is high but for other parameters, the relationship is relatively low. It can be seen from the results there is a relation between wear

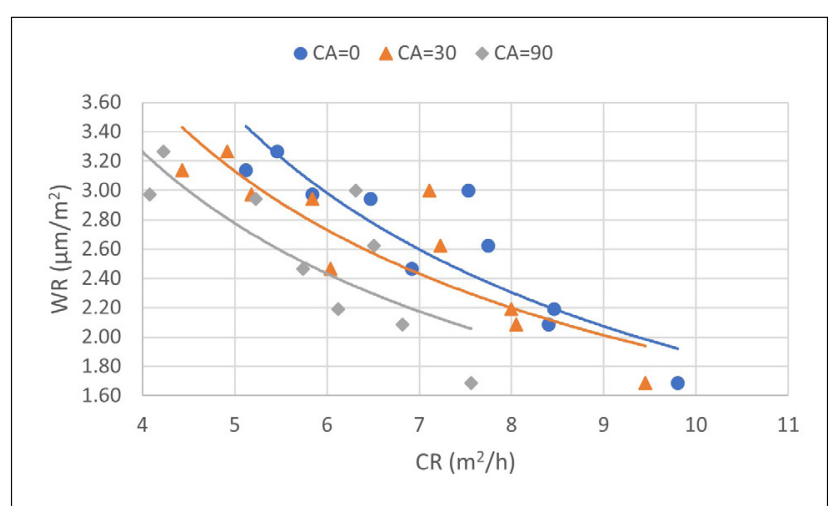

Figure 8: Wear rate versus cutting rate at different angle

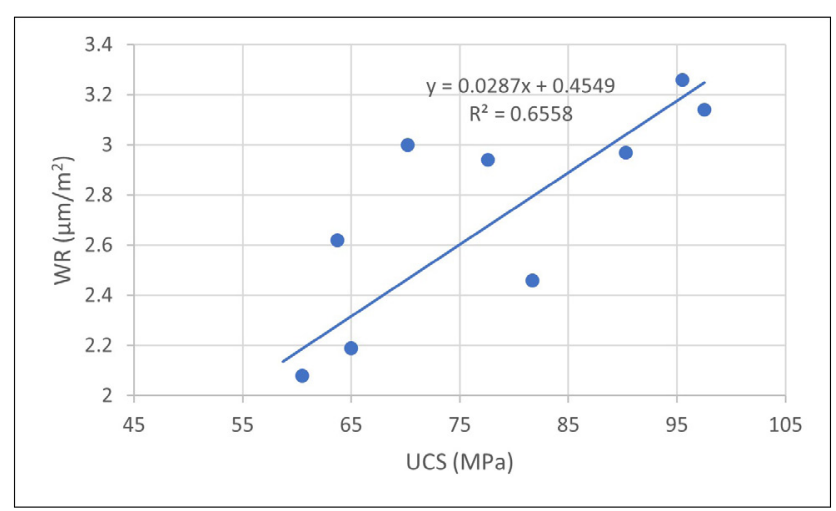

Figure 9: Wear rate versus UCS

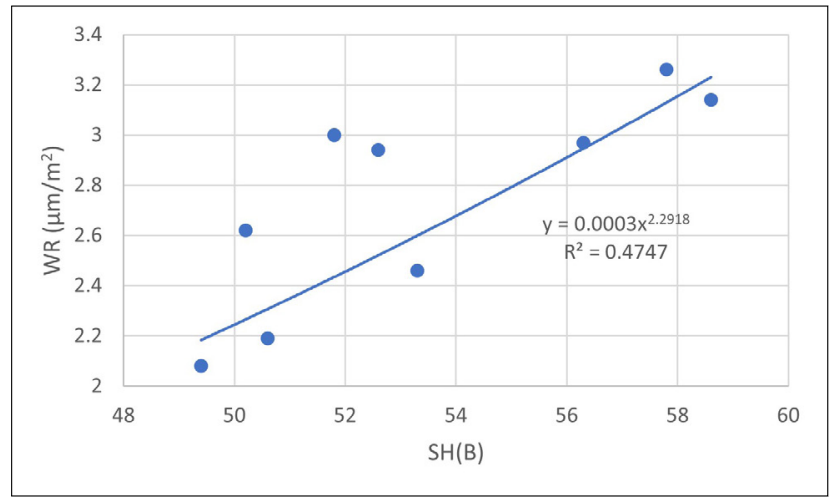

Figure 10: Wear rate versus rock hardness (B)

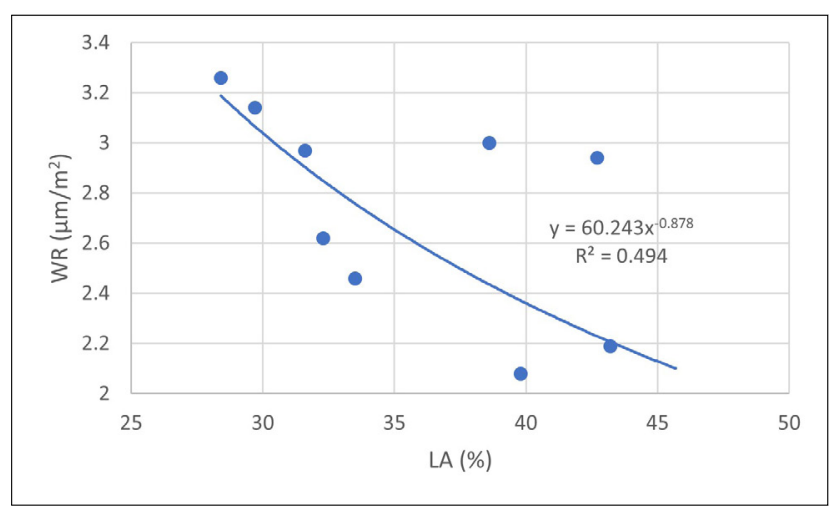

Figure 11: Wear rate versus Los Angeles abrasion

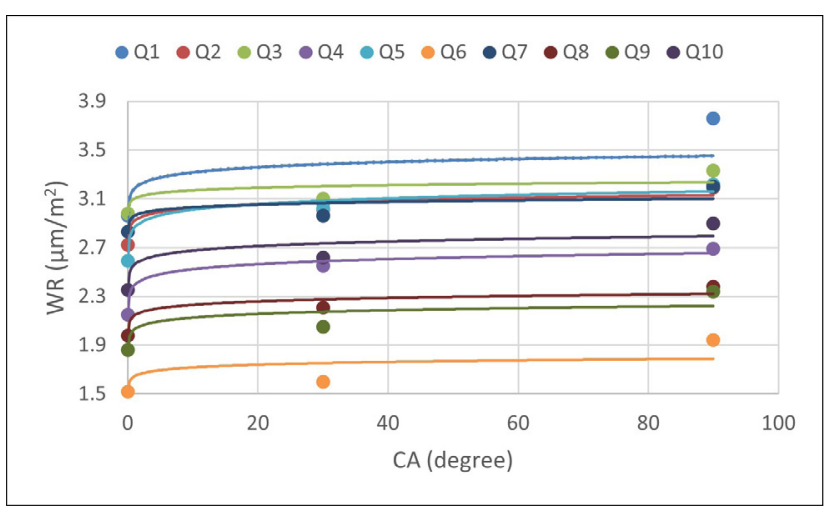

Figure 12: Wear rate versus cutting angle

rate and production rate, and by increasing the production rate of a diamond wire, the wear rate decreases.

\section{Regression analysis}

Regression analysis is a statistical method to analyze the relationship between different variables. A relationship between the dependent variable and one independent variable is simple regression, and a relationship between the dependent variable and more than one independent variable is a multiple regression analysis. In this study, the relation between the cutting rate and wear rate with different rock geomechanical properties is investigated using various regression methods. For this pur- 
pose, both linear and nonlinear regression analyses were used. The equations representing the linear and nonlinear model can be written in the following format (Kahraman et al., 2004):

$$
\begin{aligned}
& Y=c+a_{1} X_{1}+a_{2} X_{2}+a_{3} X_{3}+\ldots+a_{n} X_{n} \\
& Y=a_{1} X_{1}^{b 1} \times a_{2} X_{2}^{b 2} \times a_{3} X_{3}^{b 3} \times \ldots \times a_{n} X_{n}^{b n}
\end{aligned}
$$

Where $\mathrm{Y}$ is the predicted value according to the dependent variables, $c$ is a constant number, $a_{1}, a_{2}, a_{3}, \ldots, a_{n}$ are the intercept, $X_{1}, X_{2}, X_{3} \ldots, X_{n}$ are the independent variables and $b_{1}, b_{2}, b_{3} \ldots, b_{n}$ are the regression coefficients of $X_{1}, X_{2}, X_{3} \ldots, X_{n}$.

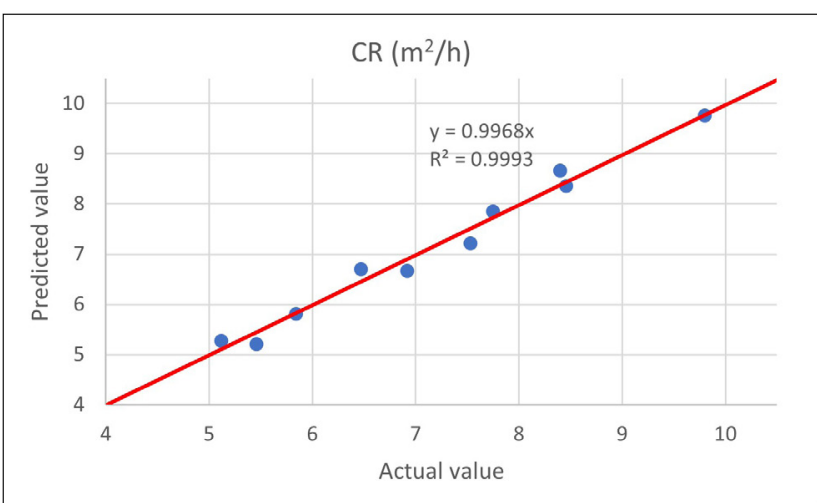

Figure 13: Predicted cutting rate versus actual cutting rate

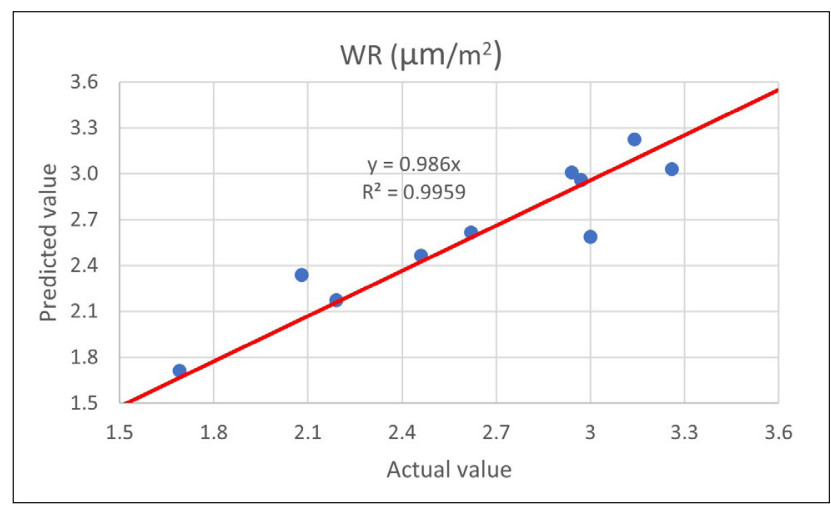

Figure 14: Predicted wear rate versus actual wear rate
The regression analysis was performed using Wolfram Mathematica software to achieve a better relationship with a high coefficient of determination between different parameters. Cutting rate and wear rate were considered dependent variables, and the previously discussed controllable and uncontrollable parameters in this study were used as independent variables. The simple and multiple regression analyses were performed using different variables according to linear and nonlinear models. The linear and nonlinear selected equations, their variables, their coefficient of determination, standard error, and f-test are summarized in Table 5.

The validation of different models was carried out by plotting the prediction value versus the estimated value during the experiments and considering the determination coefficient. The following models are the best-developed models after careful validation analysis. The coefficient of determination of the obtained models for production rates is higher than 0.9 , and for wear rate models it is higher than 0.7 , which illustrates that the obtained models can predict values very close to the actual values. The proposed model and its data is presented in Table 4. The predicted values against the estimated values are plotted in Figure 13 and Figure 14 for cutting rate and wear rate with a high coefficient of determination employed in the scatter diagram. The points on the line illustrate a correct prediction and indicates the obtained model is reasonable.

\section{Conclusion}

In this study, the diamond wire cutting method's performance in some quarries was investigated, and the effects of different parameters on the production rate and wear rate of diamond beads were studied using simple and multiple regression analyses. It was observed that the controllable and uncontrollable parameters have a significant effect on the production rate and wear rate of diamond wire. Uncontrollable parameters are mostly related to rock properties, and controllable parameters are mostly related to production aspects and machine performance. The diamond wire saw method's production

Table 4: Equation and their properties used for predicted values

\begin{tabular}{|l|l|l|}
\hline Parameters & Wear rate & Cutting rate \\
\hline Dependent variable & WR & CR \\
\hline Independent variables & UCS, B, LA, CR & UCS, B, LA, WR \\
\hline Proposed Equation & $\begin{array}{l}7.328112-\left(\left(0.05328^{*} \mathrm{UCS}\right)+\left(0.074669^{*} \mathrm{~B}\right)\right. \\
+(0.007473 * \mathrm{LA})-(0.6848 * \mathrm{CR}))\end{array}$ & $\begin{array}{l}7.465869-((0.10568 * \mathrm{UCS})+(0.178265 * \mathrm{~B}) \\
+(0.016402 * \mathrm{LA})-(0.89978 * \mathrm{WR}))\end{array}$ \\
\hline Multiple R & 0.939327978 & 0.990763826 \\
\hline R Square & 0.882337051 & 0.981612958 \\
\hline Adjusted R Square & 0.788206691 & 0.966903324 \\
\hline Standard Error & 0.238346069 & 0.271249517 \\
\hline Significance F & 0.015224447 & 0.000158346 \\
\hline F-state & 9.4 & 66.7 \\
\hline
\end{tabular}


Table 5: Selected linear and non-linear proposed equations

\begin{tabular}{|c|c|c|c|c|c|c|c|}
\hline Number & $\begin{array}{l}\text { Cutting } \\
\text { angle }\end{array}$ & $\begin{array}{l}\text { Dependent } \\
\text { variable }\end{array}$ & $\begin{array}{l}\text { Independent } \\
\text { variables }\end{array}$ & Equation & $R^{2}$ & $\begin{array}{l}\text { Std } \\
\text { Error }\end{array}$ & F-stat \\
\hline 1 & 0 & CR & $\begin{array}{l}\text { Gs, UCS, } \\
\text { B, LA }\end{array}$ & $C R=8.0105-(2.444 \times \mathrm{Gs}-0.132 \times \mathrm{UCS}+0.272 \times \mathrm{B}+0.029 \times \mathrm{LA})$ & 0.95 & 0.41 & 28.7 \\
\hline 2 & 30 & CR & $\begin{array}{l}\text { Gs, UCS, } \\
\text { B, LA }\end{array}$ & $C R=7.666-(3.104 \times \mathrm{Gs}-0.147 \times \mathrm{UCS}+0.3198 \times \mathrm{B}+0.032 \times \mathrm{LA})$ & 0.97 & 0.36 & 44.4 \\
\hline 3 & 90 & CR & $\begin{array}{l}\text { Gs, UCS, } \\
\text { B, LA }\end{array}$ & $C R=22.37-(5.933 \times \mathrm{Gs}-0.067 \times \mathrm{UCS}+0.071 \times \mathrm{B}-0.0015 \times \mathrm{LA})$ & 0.94 & 0.39 & 21.8 \\
\hline 4 & 0 & CR & $\begin{array}{l}\text { UCS, B, } \\
\text { LA, WR }\end{array}$ & $C R=7.47-(0.106 \times \mathrm{UCS}+0.178 \times \mathrm{B}+0.016 \times \mathrm{LA}-0.8998 \times \mathrm{WR})$ & 0.98 & 0.27 & 66.7 \\
\hline 5 & 30 & CR & $\begin{array}{l}\text { UCS, B, } \\
\text { LA, WR }\end{array}$ & $C R=4.478-(0.135 \times \mathrm{UCS}+0.254 \times \mathrm{B}+0.0204 \times \mathrm{LA}-0.71 \times \mathrm{WR})$ & 0.98 & 0.28 & 67.7 \\
\hline 6 & 90 & CR & $\begin{array}{l}\text { UCS, B, } \\
\text { LA, WR }\end{array}$ & $C R=10.47-(0.093 \times \mathrm{UCS}+0.069 \times \mathrm{B}-0.013 \times \mathrm{LA}-0.35 \times \mathrm{WR})$ & 0.93 & 0.41 & 19.3 \\
\hline 7 & - & WR & $\begin{array}{l}\text { Gs, UCS, } \\
\text { B, LA }\end{array}$ & $W R=10.58-(2.047 \times \mathrm{Gs}+0.065 \times \mathrm{UCS}-0.138 \times \mathrm{B}-0.007 * \mathrm{LA})$ & 0.73 & 0.36 & 3.4 \\
\hline 8 & 0 & WR & $\begin{array}{l}\text { UCS, B, } \\
\text { LA, CR }\end{array}$ & $W R=7.33-(0.053 \times \mathrm{UCS}+0.075 \times \mathrm{B}+0.008 \times \mathrm{LA}-0.684 \times \mathrm{CR})$ & 0.87 & 0.23 & 9.4 \\
\hline 9 & 30 & WR & $\begin{array}{l}\text { UCS, B, } \\
\text { LA, CR }\end{array}$ & $W R=6.057-(0.078 \times \mathrm{UCS}+0.133 \times \mathrm{B}+0.011 \times \mathrm{LA}-0.751 \times \mathrm{CR})$ & 0.82 & 0.28 & 6.4 \\
\hline 10 & 90 & WR & $\begin{array}{l}\text { UCS, B, } \\
\text { LA, CR }\end{array}$ & $W R=7.885+(0.022 \times \mathrm{UCS}-0.096 \times \mathrm{B}-0.012 \times \mathrm{LA}-0.251 \times \mathrm{CR})$ & 0.74 & 0.35 & 3.6 \\
\hline 11 & 0 & CR & $\begin{array}{l}\text { Gs, UCS, } \\
\text { B, LA }\end{array}$ & $C R=\left(19.1015 \times B^{0.919173} \times L A^{0.206694}\right) /\left(G s^{0.564804} \times U C S^{1.12615}\right)$ & 0.96 & 0.29 & 37.8 \\
\hline 12 & 30 & CR & $\begin{array}{l}\text { Gs, UCS, } \\
\text { B, LA }\end{array}$ & $C R=\left(19.8924 \times B^{1.13352} \times L A^{0.224893}\right) /\left(G s^{1.24751} \times U C S^{1.21603}\right)$ & 0.96 & 0.31 & 39.2 \\
\hline 13 & 90 & CR & $\begin{array}{l}\text { Gs, UCS, } \\
\text { B, LA }\end{array}$ & $C R=\left(2049.94 \times L A^{0.0491969}\right) /\left(G s^{3.44559} \times B^{0.161352} \times U C S^{0.502561}\right)$ & 0.94 & 0.25 & 22.5 \\
\hline 14 & 0 & CR & $\begin{array}{l}\text { UCS, B, } \\
\text { LA }\end{array}$ & $C R=\left(14.7599 \times B^{0.971497} \times L A^{0.202432}\right) / U C S^{1.23573}$ & 0.95 & 0.33 & 26.8 \\
\hline 15 & 30 & CR & $\begin{array}{l}\text { UCS, B, } \\
\text { LA }\end{array}$ & $C R=\left(11.1255 \times B^{1.25225} \times L A^{0.215847}\right) / U C S^{1.45858}$ & 0.97 & 0.41 & 56.3 \\
\hline 16 & 90 & CR & $\begin{array}{l}\text { UCS, B, } \\
\text { LA }\end{array}$ & $C R=\left(408.803 \times B^{0.154725} \times L A^{0.0275865}\right) / U C S^{1.16252}$ & 0.91 & 0.29 & 13.2 \\
\hline 17 & 0 & CR & $\begin{array}{l}\text { UCS, B, } \\
\text { LA, WR }\end{array}$ & $C R=\left(33.2216 \times B^{0.562535} \times L A^{0.148434}\right) /\left(W R^{0.174248} \times U C S^{0.963285}\right)$ & 0.97 & 0.22 & 53.2 \\
\hline 18 & 30 & CR & $\begin{array}{l}\text { UCS, B, } \\
\text { LA, WR }\end{array}$ & $C R=\left(36.7228 \times B^{0.738856} \times L A^{0.172197}\right) /\left(W R^{0.154063} \times U C S^{1.19232}\right)$ & 0.95 & 0.28 & 28.6 \\
\hline 19 & 90 & CR & $\begin{array}{l}\text { UCS, B, } \\
\text { LA, WR }\end{array}$ & $C R=\left(782.497 \times L A^{0.00221433}\right) /\left(W R^{0.08397} \times B^{0.120269} \times U C S^{1.02015}\right)$ & 0.92 & 0.24 & 16.4 \\
\hline 20 & - & WR & $\begin{array}{l}\text { UCS, B, } \\
\text { LA }\end{array}$ & $W R=\left(74.2251 \times U C S^{1.35732}\right) /\left(B^{2.16114} \times L A^{0.172897}\right)$ & 0.71 & 0.32 & 3.2 \\
\hline 21 & 0 & WR & $\begin{array}{l}\text { UCS, B, } \\
\text { LA, CR }\end{array}$ & $W R=19398.7 /\left(C R^{1.25619} \times U C S^{0.0310911} \times B^{1.58173} \times L A^{0.0134837}\right)$ & 0.82 & 0.41 & 6.7 \\
\hline 22 & 30 & WR & $\begin{array}{l}\text { UCS, B, } \\
\text { LA, CR }\end{array}$ & $W R=\left(3565.07 \times U C S^{0.128458}\right) /\left(C R^{0.885326} \times B^{1.48347} \times L A^{0.0648929}\right)$ & 0.77 & 0.33 & 2.9 \\
\hline 23 & 90 & WR & $\begin{array}{l}\text { UCS, B, } \\
\text { LA, CR }\end{array}$ & $W R=\left(977.672 \times U C S^{1.05835}\right) /\left(C R^{0.308349} \times B^{2.35633} \times L A^{0.169321}\right)$ & 0.73 & 0.45 & 3.8 \\
\hline
\end{tabular}

rate increases as uniaxial compression strength, rock hardness, specific gravity, and cutting angle decrease. The cutting rate will decrease by increasing the Los Angeles abrasion and decreasing the wheel drive diameter. A relation between the wear rate of diamond beads and the cutting rate was found with a coefficient of determination of more than 0.7 , and it was observed that by in- creasing the cutting rate, the wear rate decreases. Also, the wear rate was high in abrasive stone for a low production rate.

Furthermore, a series of simple and multiple regression analyses were performed to find the most critical operational parameters' effects on the production rate and wear rate of diamond wire. A total of 15 linear and 
good non-linear relations between the production rate and different parameters was proposed with a coefficient of correlation higher than 0.9 . Besides, 8 linear and nonlinear equations were found for the relationship between the wear rate of diamond beads and different parameters with a coefficient of determination of more than 0.7 . The validation of the proposed models was evaluated based on their coefficient of determination and plotting the actual values versus predicted values. It was found from the results that the proposed models can be used to determine the production rate and wear rate of diamond wire cutting methods based on different controllable and uncontrollable parameters.

\section{Acknowledgment}

The authors gratefully acknowledge the support of the Kushagaran Novin Pardazesh Company, Iran and Mineral engineering department of New Mexico Institute of Mining and Technology, USA.

\section{References}

Almasi, S. N., Bagherpour, R., Mikaeil, R., \& Khademian, A. (2015): Influence of cutting wire tension on travertine cutting rate. 24th International Mining Congress and Exhibition of Turkey, 1096-1102.

ASTM C131 / C131M-20, Standard Test Method for Resistance to Degradation of Small-Size Coarse Aggregate by Abrasion and Impact in the Los Angeles Machine. (2020): STM International, West Conshohocken, PA, www.astm. org, DOI:10.1520/C0131_C0131M-20.

ASTM C170-06, Standard Test Method for Compressive Strength of Dimension Stone. (2006): ASTM International, West Conshohocken, PA, www.astm.org,.DOI:10.1520/ C0170-06.

ASTM D5873-14, Standard Test Method for Determination of Rock Hardness by Rebound Hammer Method. (2014): ASTM International, West Conshohocken, PA, www.astm. org, DOI:10.1520/D5873-14.

ASTM D6473-15, Standard Test Method For Specific Gravity And Absorption of Rock For Erosion Control. (2015): ASTM International, West Conshohocken, PA, www.astm. org, DOI:10.1520/D6473-15.

Bagherpour, R., Khademian, A., Almasi, S. N., \& Aalae, M. (2014): Optimum cutting wire assembly in dimension stone quarries. Journal of Mining and Metallurgy A: Mining, 50, 1, 1-8.

Bilim, N., Karakaya, E. (2021): Penetration rate prediction models for core drilling. Mining, Metallurgy \& Exploration, 38, 359-366, DOI:10.1007/s42461-020-00322-6.

Bilodeau, M., Labrie, D., Boisclair, M., Beaudoin, R., Roy, D., Caron, G. (2008): Impact of electronic blasting detonators on downstream operations of a quarry. Mining, Metallurgy \& Exploration, 25, 1, 32-40, DOI:10.1007/BF03403383.

Bortolussi, A., Ciccu, R., Manca, P. P., Massacci, G. (1990): Simulation and optimization of rock cutting with diamond wire. APCOM ‘90, 22nd Int. Symp, 3, 163-176.
Brown, E. T. (1981): ISRM suggested methods. Rock characterization testing and monitoring. London: Royal School of Mines.

Buyuksagis, I. S. (2007): Effect of cutting mode on the sawability of granites using segmented circular diamond sawblade. Journal of Materials Processing Technology, 183, 2-3, 399-406, DOI:10.1016/j.jmatprotec.2006.10.034.

Careddu, N., Perra, E. S., Masala, O. (2019): Diamond wire sawing in ornamental basalt quarries: technical, economic and environmental considerations. Bulletin of Engineering Geology and the Environment, 78, 1, 557-568, DOI: 10. 1007/s10064-017-1112-6.

Fener, M., Kahraman, S., Ozder, M. O. (2007): Performance prediction of circular diamond saws from mechanical rock properties in cutting carbonate rocks. Rock Mechanics and Rock Engineering, 40, 5, 505-517, DOI:10.1007/s00603006-0110-y.

Ghaysari, N., Ataei, M., Sereshki, F., Mikaiel, R. (2012): Prediction of performance of diamond wire saw with respect to texture characteristics of rock. Archives of Mining Sciences, 57, 4, 887-900, DOI:10.2478/v10267-012-0058-6.

Hawkins, A. C., Antenen, A. P., Johnson, G. (1990): The diamond wire saw in quarrying granite and marble. Dimensional Stone, 44-50.

Hekimoglu, O. Z. (2014): Studies on increasing the performance of chain saw machines for mechanical excavation of marbles and natural stones. International Journal of Rock Mechanics and Mining Sciences, 72, 230-241, DOI:10.1016/j.ijrmms.2014.07.023.

Hosseini, S. M., Ataei, M., Khalokakaei, R., Mikaeil, R., Shafiee Haghshenas, S. (2019): Investigating the role of the cooling and lubricant fluids on the performance of cutting disks (case study: hard rocks). Rudarsko-GeološkoNaftni Zbornik (The Mining-Geological-Petroleum Bulletin), 34, 2, 13-25, DOI:10.17794/rgn.2019.2.2.

Kahraman, S., Fener, M., Gunaydin, O. (2004). Predicting the sawability of carbonate rocks using multiple curvilinear regression analysis. International Journal of Rock Mechanics and Mining Sciences, 41, 7, 1123-1131, DOI: 10.1016/j.ijrmms.2004.04.009.

Kahraman, S., Gunaydin, O. (2008): Indentation hardness test to estimate the sawability of carbonate rocks. Bulletin of Engineering Geology and the Environment, 67, 4, 507511, DOI:10.1007/s10064-008-0162-1.

Khoshouei, M., Jalalian, M. H., Bagherpour, R. (2020): The effect of geological properties of dimension stones on the prediction of Specific Energy (SE) during diamond wire cutting operations. Rudarsko-Geološko-Naftni Zbornik (The Mining-Geology-Petroleum Engineering Bulletin), 35, 3, 17-27, DOI:10.17794/rgn.2020.3.2.

Luo, S. Y., Liao, Y. S. (1995): Study of the behaviour of diamond saw-blades in stone processing. Journal of Materials Processing Technology, 51, 1-4, 296-308, DOI: 10.1016 /0924-0136(94)01603-X.

Mikaeil, R., Ataei, M., Yousef, R. (2013): Correlation of production rate of ornamental stone with rock brittleness indexes. Arabian Journal of Geosciences, 6, 1, 115-121, DOI:10.1007/s12517-011-0311-x. 
Mikaeil, R., Ataei, M., Yousefi, R. (2011): Application of a fuzzy analytical hierarchy process to the prediction of vibration during rock sawing. Mining Science and Technology (China), 21, 5, 611-619, DOI:10.1016/j.mstc.2011. 03.008 .

Mikaeil, R., Esmailzadeh, A., Aghaei, S., Shaffiee Haghshenas, S., Jafarpour, A., Mohammadi, J., Ataei, M. (2021): Evaluating the sawability of rocks by chain-saw machines using the PROMETHEE technique. Rudarsko-GeološkoNaftni Zbornik (The Mining-Geological-Petroleum Bulletin), 36, 1, 25-36, DOI:10.17794/rgn.2021.1.3.

Mikaeil, R., Sohrabian, B., Ataei, M. (2018): The study of energy consumption in the dimension stone cutting process. Rudarsko-Geološko-Naftni Zbornik (The Mining-Geology-Petroleum Engineering Bulletin), 33, 4, 1-7, DOI: 10.17794/rgn.2018.4.6.

Najmedin Almasi, S., Bagherpour, R., Mikaeil, R., Ozcelik, Y. (2017): Analysis of bead wear in diamond wire sawing considering the rock properties and production rate. Bulletin of Engineering Geology and the Environment Volume, 76, 4, 1593-1607, DOI:10.1007/s10064-017-1057-9.

Ozcelik, M., Leventeli, Y. (2019): Geological features and marble production qualities of western Turkey. Mining of Mineral Deposits, 13, 1, 66-71, DOI:10.33271/mining13. 01.066 .

Özçelik, Y., Kulaksız, S., Çetin, M. . (2002): Assessment of the wear of diamond beads in the cutting of different rock types by the ridge regression. Journal of Materials Processing Technology, 127, 3, 392-400, DOI:10.1016/ S0924-0136(02)00429-6.
Ozcelik, Y., Yilmazkaya, E. (2011): The effect of the rock anisotropy on the efficiency of diamond wire cutting machines. International Journal of Rock Mechanics and Mining Sciences, 48, 4, 626-636, DOI:10.1016/j.ijrmms.2011 .04 .006 .

Rajpurohit, S. S., Sinha, R. K., Sen, P., Adak, V. (2020): Effect of the rock properties on sawability of granite using diamond wire saw in natural stone quarries. Arabian Journal of Geosciences, 13, 21, 1-15, DOI:10.1007/s12517-02006139-3.

Ranjkesh Adarmanabadi, H., Rasti, A., Razavi, M. (2021): The effects of cement kiln dust on the soil electrical resistivity. American Journal of Engineering and Applied Sciences, 14, 1, 51-63, DOI:10.3844/ajeassp.2021.51.63.

Sadegheslam, G., Mikaeil, R., Rooki, R., Ghadernejad, S., Ataei, M. (2013): Predicting the production rate of diamond wire saws using multiple nonlinear regression analysis. Geosystem Engineering, 16, 4, 275-285, DOI:10.108 0/12269328.2013.856276.

Sengun, N., Altindag, R. (2013): Prediction of specific energy of carbonate rock in industrial stones cutting process. Arabian Journal of Geosciences, 6, 4, 1183-1190, DOI: 10.1007/s12517-011-0429-x.

Yassien, M. A., Sayed, M. A., Boghdady, G. Y., Ali, M. A. M., Mohamed, A. S. (2020): Experimental research into the effect of some operation factors and rock properties on the rate of penetration. Mining of Mineral Deposits, 14, 1, 36-43, DOI:10.33271/mining14.01.036. 


\section{SAŽETAK}

\section{Statistička analiza utjecaja kontroliranih i nekontroliranih parametara na rad dijamantnom žičnom pilom, prikaz slučaja}

Danas se u najvećemu broju rudnika i kamenoloma upotrebljava dijamantna žična pila za razne operacije na čelima radilišta. Uporabom metalne žice (ili kabela) na koju su dodani dijamantni zupci mogu se rezati veliki blokovi arhitektonsko-građevnoga kamena. Pri tomu rezanje ovisi o nizu parametara od kojih se neki mogu, a neki ne mogu kontrolirati. Oni koji se ne mogu kontrolirati jesu inženjerska svojstva stijena, a oni koji se mogu kontrolirati jesu operativne varijable i svojstva stroja. Iznos rezanja/proizvodnje najkritičnija je varijabla prema utjecaju na iznos proizvodnje. Svojstva stijena kao čvrstoća, tvrdoća i abrazivnost te operativne vrijednosti poput kuta rezanja, promjera pogonskoga kotača najvažnije su varijable koje utječu na proizvodnju žičnih pila. Procijenjen je odnos između brzine rezanja i trošenja dijamantnih zubaca i opaženo je kako različite varijable utječu na povećanje ili smanjivanje iznosa proizvodnje. Analizirane su metodama jednostavne i višestruke regresije, uključivši sve spomenute varijable, te su predložene jednadžbe kojima se opisuju opažene pojave.

\section{Ključne riječi:}

metoda rezanja dijamantnom žicom, iznos rezanja, iznos trošenja, regresijska analiza, kontrolirani i nekontrolirani parametri

\section{Author's contribution}

Arezou Rasti (Mining and Geotechnical Engineer) Contributed to idea development and designed the study, participated in conceptualization, methodology, data collection and formal analysis, visualization, supervision, validation and the writing of the manuscript. Hamid Ranjkesh Adarmanabadi (Master student) Contributed to the design of the study, methodology, data collection and performed tests, performed field work, data analyses and visualization, and participated in the writing of the manuscript. Mohammad Reza Sahlabadi (Ph.D. Candidate) performed field work, performed laboratory tests, contributed with writing and reviewing the manuscript. 